\title{
Răsunetul cardiovascular al obezității la copil
}

\author{
Georgiana Russu' ${ }^{1}$ Otilia-Elena Frăsinariu² ${ }^{2}$ Laura Trandafir ${ }^{3}$ \\ ${ }^{1}$ Clinica de Cardiologie Pediatrică, \\ Spitalul Clinic de Urgenţă pentru Copii „Sf. Maria“, Iaşi, România \\ ${ }^{2}$ Clinica I Pediatrie, Universitatea de Medicină şi Farmacie „Gr. T. Popa“, Iaşi, România \\ ${ }^{3}$ Clinica III Pediatrie, Universitatea de Medicină şi Farmacie „Gr. T. Popa“, Iaşi, România
}

\begin{abstract}
REZUMAT
Obezitatea şi suferința cardiovasculară determinată de această boală de nutriție sunt tot mai frecvente în rândul populației pediatrice. La copilul obez apar precoce semne ale disfuncției cardiovasculare: creşterea rigidității arteriale, modificări precoce de ateroscleroză, modificări ale structurii şi funcției miocardului. Aceste modificări sunt rezultatul adipozității excesive care deseori acționează independent de alte comorbidități determinate de obezitate, cum ar fi dislipidemia şi rezistența la insulină. Obezitatea din copilărie predispune la risc crescut de morbiditate şi mortalitate de cauză cardiovasculară în perioada de adult. Desfăşurarea reală a unui program complex de prevenție, diagnostic precoce şi tratament al obezității copilului va reduce incidența patologiei cardiovasculare la viitorii adulți.
\end{abstract}

Cuvinte cheie: obezitate, copil, ateroscleroză, funcție miocardică

\section{INTRODUCERE}

Obezitatea este definită ca indice de masă corporală (IMC) egal sau peste percentila 95 pentru vârstă şi sex. Un raport al National Health and Nutrition Survey atrage atenția asupra creşterii dramatice a prevalenței obezității de la $7 \%$ la $18 \%$, în ultimii 30 de ani, la toate grupele de vârstă în SUA (1). Se însoțeşte de creşterea incidenței diabetului zaharat tip 2 (DZ 2), hipertensiunii arteriale (HTA) şi aterosclerozei (ATS) la adult. Recunoscând importanța obezității şi implicațiile ei cardiovasculare, American Heart Association a identificat obezitatea ca factor de risc independent, important şi influențabil pentru boală (2). Meta-analiza efectuată de Serdula şi colaboratorii a evidenţiat că riscul apariției obezităţii la adult este cel puțin dublu pentru copiii obezi comparativ cu cei cu IMC normal, corelându-se cu vârsta de debut a obezității. Aproximativ o treime dintre preşcolarii obezi şi jumătate dintre copiii de vârstă şcolară au devenit obezi ca adulți. Riscul obezitătii la adult a fost mai mare la copiii cu obezitate severă şi la cei la care obezitatea s-a instalat la vârstă mai mare (3). Adulții care au fost obezi în copilărie au prevalență mai mare de factori de risc pentru boală cardiovasculară, inclusiv HTA şi dislipidemie, comparativ cu cei care au avut greutate normală. S-a demonstrat, de asemenea, că obezitatea în copilărie şi adipozitatea centrală au crescut riscul apariției sindromului metabolic la adult (4).

\section{Programăm copilul să fie obez?}

Pantele ascendente ale curbelor de frecvență a unor boli, în timp ce fondul genetic al populațiilor este stabil, au fost explicate recent prin intervenția unor reglări epigenetice, determinate de mediu, care însoțesc evoluția biologică din perioada embrionară până la moarte (5). A fost alcătuit un cata$\log$ (încă perfectibil) de boli complexe manifeste la adult, dar programate fetal fie cu ereditate dovedită, fie dobândite prin resetări epigenetice (obezitate comună, ateroscleroză, diabet zaharat tip 2 etc.).

Sub influența mediului, funcția genelor se modifică reversibil fără modificarea secvențelor ADN prin: metilarea $\mathrm{ADN}$, modificări fizice în structura cromatinei şi acțiunea unor molecule ARN non-co- 
dante. Rezultă o modulare genică cu impact asupra fenotipurilor unor boli, ca reacții de răspuns la factori din mediu (factori de risc epigenetic): toxice, factori nutriționali, infecții, noxe cancerigene, stres.

Modificările epigenetice se pot transmite prin gameți, sunt trans-generaționale, fapt demonstrat de perpetuarea pe mai multe generaţii a obezităţii şi diabetului zaharat tip 2. De asemenea, s-a demonstrat corelația pozitivă a mortalității prin diabet şi boli cardio-vasculare cu starea nutrițională a părinților şi bunicilor (6).

Boekelheide et al. (2012) studiind la adulți, după 50 de ani, efectele înfometării gravidelor din Olanda în timpul celui de Al Doilea Război Mondial, a constatat că înfometarea în primul trimestru de sarcină se corelează cu intoleranța la glucoză, afecțiuni cardio-vasculare, hipertensiune arterială (HTA), dislipidemie, obezitate, perturbări afective. Înfometarea din al doilea trimestru s-a corelat cu intoleranță la glucoză, boli pulmonare şi renale, iar cea din trimestrul al treilea cu intoleranță la glucoză şi afecțiuni cardio-vasculare (7).

Aportul nutriţional şi echilibrul metabolic matern se reflectă asupra greutății la naștere considerată clasic ca marker al riscului de obezitate la copil şi viitorul adult.

Numeroase studii au demonstrat că nutriția deficitară intrauterină, reflectată prin greutatea mică la naştere, nou-născuți mici pentru vârsta gestațională (,fenotip economic") vor dezvolta uneori chiar din adolescență bolile metabolice ale adultului. Excluzându-se fetuşii cu greutate mică prin patologie ereditară sau infecțioasă, s-a raportat prevalența crescută a sindromului metabolic, a bolilor coronariene, HTA, dislipidemie, rezistență la insulină (8).

La copiii cu greutate mică prin prematuritate (greutate corespunzătoare vârstei gestaționale) valorile insulinei plasmatice din cordonul ombilical au fost mai mari şi persistente față de cele ale nounăscuților la termen (9).

Greutatea mare la naştere, în special dacă se asociază cu diabet gestațional matern, se corelează cu valori crescute ale insulinei plasmatice, obezitate în copilărie şi ulterior în perioada de adult şi dezvoltarea sindromului metabolic.

Obezitatea gravidei se însoțeşte de complicaţii gestaționale: macrosomie fetală, diabet gestațional, preeclampsie. Chirurgia bariatrică aplicată femeilor obeze reduce semnificativ riscul de diabet zaharat şi HTA la fetuşi (10). Mediul intrauterin modificat de obezitatea maternă influențează programul de dezvoltare fetală predispunând viitorul adolescent şi adult la boli cardio-vasculare, obezitate, ateroscleroză accelerată.
Mediul uterin perturbat şi malnutriția fetală (prin deficit sau exces) împreună cu alți factori de risc epigenetic perturbă comenzile genice cardiovasculare şi metabolice, uneori ireversibil, reflectându-se de-a lungul vieții prin apariția sindromului metabolic, a obezităţii (uneori cu debut precoce), HTA, hiperinsulinism, dislipidemie, cuprinse în categoria de boli programate fetal (11).

Sporul ponderal exagerat de la naştere până la 18 luni se asociază cu supraponderalitate sau obezitate ulterior, adipozitate centrală, HTA şi valori crescute ale proteinei $\mathrm{C}$ reactive, determinând îngroşarea exagerată a peretelui carotidei măsurat la vârsta de 8 ani $(12,13)$.

Alimentaţia naturală este o condiție cheie în profilaxia riscurilor cardio-vasculare, a obezităţii şi a numeroase perturbări metabolice.

Metaanaliza OMS (2013) pe 75 de studii observaționale a demonstrat efectul pozitiv al alăptării în prevenirea obezității şi HTA din perioada de adult (14). În acelaşi sens se înscrie studiul efectuat pe 822 de tineri olandezi (18-28 de ani), care a demonstrat că alimentația exclusivă cu lapte matern a avut un efect protector semnificativ asupra masei grase corporale şi viscerale (IMC, perimetrul abdominal şi raportul perimetru abdominal-circumferinţa şoldurilor). Mai mult, s-a demonstrat o corelație semnificativă între alimentația naturală a prematurilor şi profilul lipidic normal ulterior (15).

\section{Remodelarea vasculară}

Obezitatea este recunoscută ca fiind predictor independent şi factor de risc major, dar influenţabil, pentru ATS coronariană şi boala coronariană acută. Obezitatea acționează asupra vaselor prin: disfuncție endotelială generalizată, accelerarea proliferării, migrării şi hipertrofiei celulelor musculare netede arteriale şi recrutarea macrofagelor în peretele vascular. Disfuncția endotelială generalizată şi vasodilataţia ulterioară sunt considerate pasul inițial în patogeneza ATS, urmate de depozitarea colesterolului cu densitate mică (LDL). Dislipidemia asociată obezității, rezistența la insulină, adipocitokinele eliberate de țesutul adipos accelerează şi mai mult procesul de ATS (16). A fost raportată valoarea crescută a grosimii intima media carotidiană (IMT) evaluată prin ecografie Doppler vasculară la copii şi adolescenți obezi comparativ cu copiii de aceeaşi vârstă cu IMC normal (17). Conceptul de vârstă vasculară s-a impus prin utilizarea clinică a acestui parametru pentru evaluarea IMT pe scara percentilelor pentru populația adultă de aceeaşi rasă şi sex (18). După evaluarea a 70 de copii cu vârste cuprinse 
între 6-19 ani, cu obezitate şi factori de risc pentru ATS (dislipidemie, HTA, rezistenţă la insulină şi expunere la fumul de țigară), Le şi colaboratorii au raportat $75 \%$ cazuri cu vârstă vasculară similară unui adult de 45 de ani (19).

Rigiditatea arterială se asociază cu risc cardiovascular crescut la adult. Un sistem vascular cu elasticitate normală solicită mai puţin cordul, creşte perfuzia coronariană şi se asociază cu reducerea vitezei de producere a ATS. Complianța arterială creşte cu vârsta copilului, deoarece arterele devin mai mari odată cu creşterea şi dezvoltarea. La copiii cu obezitate a fost raportată modificarea unor parametri biofizici ai aortei, care reflectă scăderea elasticitătii acestui vas (20). De asemenea, a fost demonstrat efectul obezității asupra proprietăților peretelui arterei pulmonare, scăderea elasticităţii şi creşterea rigidității participând la apariția şi progresia hipertensiunii pulmonare şi poate fi identificată înaintea apariției semnelor clinice (21).

Disfuncția sistemului nervos autonom asociată obezității la copii reduce variabilitatea vagală a ritmului cardiac (22), ca şi diminuarea sensibilității baroreceptorilor, cu rol esențial în reglarea tensiunii arteriale (TA) (23).

HTA şi stadiul de pre-HTA sunt complicații frecvente şi precoce la copiii cu obezitate, frecvența crescând în ultimele decade la $4 \%$, respectiv $10 \%$ (24). HTA copilului este un predictor important pentru HTA adultului, dar este subdiagnosticată. Identificarea şi tratarea tinerilor hipertensivi întâmpină dificultăți deoarece valorile TA variază de la un moment la altul în funcție de numeroşi factori fiziologici şi din mediul înconjurător. De aceea, determinarea TA în ambulator permite o evaluare reală şi permite stratificarea riscului şi estimarea prognosticului cardiovascular. HTA de halat alb, foarte frecventă în rândul copiilor (40\%), este o sursă importantă de eroare diagnostică (25).

$\mathrm{Au}$ fost identificate trei mecanisme fiziopatologice de apariție a HTA la copiii obezi: disfuncția sistemului nervos autonom, rezistența la insulină şi modificarea structurii şi funcției vaselor.

Hiperactivitatea sistemului nervos autonom simpatic are drept consecință manifestări cardiovasculare, creşterea nivelului catecolaminelor plasmatice şi creşterea activităţii sistemului nervos simpatic periferic, reflectându-se clinic prin creşterea TA şi a frecvenței cardiace în repaus (26).

Rezistența la insulină a copilului obez a fost implicată în patogenia HTA, numeroase studii raportând o corelație pozitivă între insulinemie şi TA de repaus (27). S-a sugerat că rezistența la insulină asociată obezității poate preveni consumul gluco- zei indus de insulină, dar păstrând efectul asupra retenției de sodiu, ceea ce determină supraîncărcare cronică de volum şi menținerea TA la valori crescute.

Alterarea structurii peretelui vascular şi creşterea rigidității arteriale reprezintă o altă buclă patogenetică a HTA din obezitate. Kortelainen şi colaboratorii au semnalat greutate crescută a cordului şi prezența plăcilor de grăsime şi depozite de calciu în peretele coronarelor la 210 necropsii efectuate la copiii obezi cu vârste cuprinse între 5-10 ani, care suferiseră moarte violentă (28).

În obezitate, țesutul adipos compus din adipocite mature, preadipocite, celule endoteliale şi macrofage prezintă particularități. Fiziologic, adipocitele mature sunt celule cu activitate endocrină şi paracrină ce secretă un mare număr de mediatori cu rol în diverse procese metabolice. Cel mai cunoscut este leptina, hormon care acționează ca reglator feedback ce suprimă senzația de foame la nivel hipotalamic. La obezi, leptina circulantă este crescută, corelat cu adipozitatea. A fost demonstrată legătura dintre leptină şi HTA: leptina reglează activitatea Na, K-ATPazei, modificând schimburile renale de sodiu, activează axa renină-angiotensinăaldosteron şi sistemul nervos simpatic, pare a avea legătură cu rezistența la insulină şi acționează concertat cu alte citokine proinflamatorii, inducând stres oxidativ vascular şi HTA (29).

Țesutul adipos în exces este format din adipocite hipertrofiate şi macrofage şi devine disfuncțional, secretând adipokine proinflamatorii: interleukina-6, factorul de necroză tumorală- $\alpha$, inhibitorul activatorului de plasminogen şi proteina $\mathrm{C}$ reactivă. Adiponectina, proteină secretată din abundență de țesutul adipos, este un stimulator important al activității sintetazei oxidului nitric şi conferă protecție împotriva stresului oxidativ şi rezistenţei la insulină. Nivelele circulante de adiponectină sunt scăzute în obezitate, producerea ei fiind suprimată de adipokinele proinflamatorii. Luate împreună, aceste fenomene modifică metabolismul glucozei şi lipidelor, determinând disfuncție endotelială vasculară şi accelerând procesele de ateroscleroză la nivelul peretelui vascular, crescând astfel riscul cardiometabolic (30).

Rinichiul este atât cauza, cât şi victima HTA. În prezența rezistenței la insulină, dislipidemia şi perturbările metabolismului glucozei, favorizante ale HTA, pot contribui la afectarea renală prin pierderea graduală a nefronilor. Modificarea structurală şi funcţională a nefronilor contribuie la creşterea TA. La copiii pre-hipertensivi a fost demonstrată reducerea filtrării glomerulare, asociată cu supraîncăr- 
care de volum şi proteinurie, ceea ce sugerează că şi valorile uşor crescute ale TA prezintă risc de afectare renală (31).

Tratamentul preHTA şi HTA stadiul 1 la copiii obezi constă în modificarea stilului de viaţă şi reducerea greutăţii corporale. Medicamentele hipotensive sunt recomandate doar începând cu stadiul 2 de HTA (32). Efectul benefic al scăderii în greutate pentru reducerea valorilor TA a fost demonstrat. Astfel, o meta-analiză a studiilor privind prevenția obezităţii şi a complicațiilor ei a evidențiat eficiența măsurilor care au ca obiectiv atât dieta, cât şi exercițiul fizic privind reducerea IMC şi normalizarea TA (33).

\section{Apneea de somn şi obezitatea}

Obezitatea şi supraponderalitatea sunt factori de risc cunoscuți pentru apneea de somn, care contribuie la apariția complicațiilor cardiovasculare prin variate mecanisme fiziopatologice. Episoadele recurente de obstrucție parţială sau totală a căilor respiratorii în somn, având drept consecinţă hipoxie şi hipercapnie, determină modificări neuroumorale, stres oxidativ, răspuns inflamator şi disfuncție metabolică. Astfel, activarea sistemului nervos simpatic şi disfuncția endotelială determinată de răspunsul inflamator din vasele sanguine indus de eliberarea de mediatori pro-inflamatori (proteina $\mathrm{C}$ reactivă, endotelina-1) duc la apariţia HTA. Alte mecanisme activate de apneea de somn în obezitate sunt: alterarea activității baroreflexe arteriale, perturbarea funcției renale, hiperleptinemia, rezistența la insulină, activarea sistemului renină-angiotensină şi a stresului oxidativ (34). Episoadele frecvente de hipoxie induc episoade repetitive de vasoconstricție pulmonară care au drept consecință apariţia hipertensiunii pulmonare (35).

\section{Suferința cordului}

Obezitatea este asociată cu creşterea nevoilor metabolice determinate de cantitatea crescută de țesut adipos; creşterea presarcinii determinată de creşterea volumului sanghin se asociază cu cea a postsarcinii determinată de rigiditatea şi rezistența arterială. În consecință, apare hipertrofie excentrică şi concentrică a ventriculului stâng (VS), corelat cu gradul şi durata obezităţii şi asocierea cu HTA (36). Este dovedit că dimensiunile atriului stâng (AS) şi ventriculului stâng (VS), ca şi masa VS la copiii obezi sunt mai mari decât la copiii cu IMC normal.

Țesutul adipos epicardic depozitat în jurul inimii între pericard şi peretele exterior al miocardului este propus ca factor de risc cardiovascular (37).
Cuantificarea ecocardiografică a țesutului adipos epicardic a demonstrat corelație pozitivă cu depozitele de țesut adipos visceral. Există o cantitate mică de țesut adipos epicardic şi la subiecții cu IMC normal, dar valoarea limită considerată normală nu a fost încă stabilită. Totuşi, un studiu recent a propus cifra de 4,1 mm ca valoare de referință la copil (38). Dimensiunile depozitului adipos epicardic se corelează cu rezistența la insulină, boala coronariană, grosimea peretelui carotidei şi rigiditatea arterială la adult. Măsurarea țesutului epicardic poate fi utilă pentru evaluarea riscului cardiovascular la copil.

Modificările macroscopice ale cordului la copilul obez sunt: greutate crescută a inimii, hipertrofie a VS, VD, ca şi dilatare ventriculară. Microscopic, se observă hipertrofia miocitelor şi fibroză miocardică, urmate de apoptoză şi necroză a miocitelor, rarefierea capilarelor şi infiltrat inflamator (39). Conceptul de lipotoxicitate în cardiomiopatia obezului are la bază descoperirea (experimentală) depozitelor adipoase intra şi intercelular, determinând degradarea miocitelor, apoptoză, atrofie şi disfuncție cardiacă (40). Similar, studii efectuate la om au demonstrat conținut crescut de trigliceride la nivel miocardic (41).

Prima modificare a funcției cardiace care apare în obezitate este disfuncția diastolică , sub forma tulburării de relaxare şi/sau a complianței miocardului. Aceasta apare independent sau în asociere cu alte modificări caracteristice cardiomiopatiei din obezitate, cum ar fi hipertrofia VS. Mai mult, severitatea disfuncției diastolice este direct proporțională cu durata obezității (42). Hipertrofia VS determină, de asemenea, ischemie subendocardică, fenomen accentuat de prezenţa depozitului adipos epicardic care, prin dimensiunea lui, împiedică mecanica normală a cordului (43).

Treptat se instalează şi disfuncție sistolică, proporțional cu severitatea obezității, demonstrată de tehnici moderne de ecocardiografie (44).

Adipozitatea viscerală în cantitate crescută este în mod independent asociată cu riscul de boală cardiovasculară. Țesutul gras este tot mai mult recunoscut ca organ metabolic activ. Când capacitatea de stocaj a țesutului adipos atinge maximum, excesul de grăsime poate fi depozitat în țesuturi ectopice, cum ar fi muşchiul scheletic, inima, vasele şi rinichii, determinând un status insulino-rezistent. Acesta are ca rezultat lipoliza cu eliberare în exces de acizi graşi liberi şi alte peptide derivate din adipocite, cum ar fi leptina, rezistina, factorul de necroză tumorală $\alpha$, adiponectin, inhibitorul activatorului de plasminogen şi interleukina 6 (45). 
Tresutul adipos este infiltrat cu macrofage. Majoritatea citokinelor inflamatorii eliberate de țesutul adipos provin din macrofagele care infiltrează țesutul adipos disfuncțional. Mediul citokinic creat autoîntreține recrutarea macrofagelor. Cancello şi colaboratorii au demonstrat îmbunătăţirea statusului inflamator odată cu reducerea infiltratului macrofagic din țesutul adipos şi ameliorarea sensibilității la insulină la subiecții obezi care au slăbit (46).

\section{Efectul cardiovascular al tratamentului obezității}

Ghidurile actuale recomandă modificarea stilului de viață, a dietei, reducerea activităţilor sedentare şi program de exerciţii fizice pentru prevenirea şi tratarea obezității copilului. IMC este folosit ca reper al succesului tratamentului. Măsurile mai agresive, cum ar fi tratamentul medicamentos şi chirurgia bariatrică, sunt rezervate adolescenților cu obezitate severă la care măsurile terapeutice convenționale au eşuat (47). Exerciţiul fizic are efecte favorabile asupra IMC şi a dimensiunilor adipozităţii pe termen scurt (10 săptămâni) şi mediu (4 luni). Multe studii au demonstrat îmbunătăţirea funcției cardiace şi vasculare după 6 luni de măsuri dietetice şi exerciţiu fizic, cu ameliorarea semnificativă a disfuncției diastolice (48). La adolescenții cu obezitate morbidă, chirurgia bariatrică a îmbunătățit geometria cardiacă, s-a corectat funcția diastolică şi s-a redus grăsimea epicardică; evaluarea a fost făcută după $10 \pm 3$ luni postoperator (49). Huang şi colab. au observat îmbunătățirea statusului moleculelor de adeziune (selectina E), a parametrilor fibrinolizei (inhibitorul activatorului de plasminogen), a valorii trigliceridelor şi a homeostaziei glucozei la pacienții care au obținut reducerea IMC după 6 luni de modificare a stilului de viață (50). Aceste îmbunătățiri au fost însoțite de ameliorarea factorilor de risc cardiometabolic, adipozității şi biomarkerilor.

\section{CONCLUZII}

Obezitatea, boală programată fetal, cu debut oricând de-a lungul copilăriei sub influența unui context de factori de risc, se însoțeşte (proporțional cu severitatea) de afectare cardiovasculară. Obezitatea la copil şi adolescent se asociază cu risc cardiovascular pe termen scurt şi mediu, care include modificări hemodinamice şi modificări structurale şi funcţionale la nivelul inimii şi vaselor. Rigiditatea arterială şi capacitatea de relaxare a VD se modifică fiziologic odată cu înaintarea în vârstă. Obezitatea în copilărie accelerează aceste procese fiziologice, crescând riscul de apariție a bolii cardiovasculare în perioada de adult, dar determină afectare cardiovasculară şi la copil. Programele de prevenție, diagnostic şi tratament a obezității la copii şi adolescenți trebuie să includă identificarea precoce a disfuncției cardio-vasculare şi monitorizarea ei pe măsura corectării IMC. Vârsta tânără asigură reversibilitatea efectelor secundare cardiovasculare ale obezităţii, cu condiția includerii precoce a bolnavului în program recuperator.

Conflict of interest: none declared Financial support: none declared 